\title{
Oznaczenie fentanylu i remifentanylu we krwi metodą chromatografii cieczowej sprzężonej z tandemową spektrometrią mas LC-MS/MS
}

\author{
Determination of fentanil and remifentanil in blood with liquid chromatography coupled with \\ tandem mass spectrometry LC-MS/MS
}

\author{
Tomasz Janus ${ }^{1}$, Barbara Potocka-Banaś ${ }^{1 凶}$, Ewa Jasionowicz ${ }^{1}$, Krzysztof Borowiak$^{1}$, Izabela Polewczak ${ }^{2}$ \\ 1 Pomorski Uniwersytet Medyczny w Szczecinie, Zakład Toksykologii Klinicznej i Sądowej, al. Powstańców Wlkp. 72, 70-111 Szczecin \\ Pomeranian Medical University in Szczecin, Department of Clinical and Forensic Toxicology \\ ${ }^{2}$ Wielospecjalistyczny Szpital Wojewódzki w Gorzowie Wielkopolskim, Oddział Hematologii i Chorób Rozrostowych Układu Krwiotwórczego z Pododdziałem \\ Dziennej Hematologii, ul. Dekerta 1, 66-400 Gorzów Wlkp. \\ Provincial Multidisciplinary Hospital in Gorzów Wielkopolski, Department od Hematology \\ $\checkmark$ barbara.potocka@vp.pl
}

\begin{abstract}
Introduction: Fentanil and remifentanil are both opioid drugs. As synthetic compounds they act as agonists on the opioid brain receptors. They are widely used in neuroleptanalgesia as well as in various clinical procedures. Due to their wide applicability, there is a need to develop appropriate toxicological assays for qualitative determination and to quantify the estimation of fentanil and remifentanil in biological material.

The aim of this study was to develop a method for the parallel qualitative and quantitative determination of fentanil and remifentanil in whole blood with the determination of analytical limit parameters.

Materials and methods: Biological material in the above study was whole blood collected from the Blood Donation Station in Szczecin, Poland. Samples for tests were obtained by adding reference substances (fentanil, remifentanil, fentanil- $\mathrm{d}_{5}$ with known concentrations) to whole blood. Analytes were isolated from the matrix by liquid-liquid extraction with ethyl acetate. The obtained samples were further analyzed by high-performance liquid chromatography-tandem mass spectrometry
\end{abstract}

(LC-MS/MS). The following parameters were calculated based on measurements: mean, standard deviation, relative standard deviation, and coefficient of variation. To increase the sensitivity of the LC-MS/MS method and to optimize the procedure a potential range over $0-300 \mathrm{~V}$ and $\mathrm{DP}=80$ was chosen. Collision energy was $35 \mathrm{~V}$. The high resolution of the apparatus allowed the selection of a narrow signal range for each compound: fentanil- $\mathrm{d}_{5}-188.143 \pm 0.0047 \mathrm{Da}$, fentanil $-188.1445 \pm 0.0043 \mathrm{Da}$ and remifentanil - $317.186 \pm 0.007 \mathrm{Da}$.

Results: The results obtained from the analysis of fentanil and remifentanil samples allowed for plotting calibration curves within the range of $1-200 \mathrm{ng} / \mathrm{mL}$, which showed linearity. Conclusion: The obtained results allowed the identification and the quantitative determination of fentanil and remifentanil in whole blood. Liquid chromatography-tandem mass spectrometry is suitable for practical applications in both forensic and clinical toxicology.

Keywords: fentanil; remifentanil; liquid chromatography-tandem mass spectrometry.

\begin{abstract}
ABSTRAKT
Wstęp: Fentanyl i remifentanyl to syntetyczne związki należące do grupy opioidów działające agonistycznie na receptory opioidowe. Są powszechnie używane w neuroleptanalgezji w różnych zabiegowych dyscyplinach medycznych, jak: ginekologia, kardiochirurgia, ortopedia oraz onkologia. Ze względu na szerokie zastosowanie i efektywne biologicznie działanie w niskich stężeniach coraz częściej zachodzi potrzeba zarówno jakościowej identyfikacji, jak i jednoczesnego ustalenia stężeń fentanylu i remifentanylu w materiale biologicznym. Dlatego też opracowanie czułych i zarazem precyzyjnych oraz pewnych procedur analityczno-toksykologicznych jest istotnym problemem dla diagnostów pracujących w specjalistycznych laboratoriach toksykologicznych.

Celem pracy było opracowanie diagnostycznej procedury jednoczesnego jakościowego i ilościowego oznaczenia fentanylu oraz remifentanylu we krwi pełnej i ustalenie optymalnych parametrów analitycznych.
\end{abstract}

Materiały i metody: Materiałem biologicznym była krew pełna zakupiona w Wojewódzkiej Stacji Krwiodawstwa w Szczecinie. Próby poddawane badaniom uzyskano poprzez obciążenie krwi pełnej wzorcami: fentanylu, remifentanylu i fentanylu- $d_{5}$ o znanych stężeniach. Izolację analitów z matrycy przeprowadzono techniką ciecz-ciecz, stosując jako czynnik ekstrahujący octan etylu. Uzyskane próbki analizowano z wykorzystaniem wysokosprawnej chromatografii cieczowej sprzężonej z tandemowym spektrometrem mas (LC-MS/MS). Na podstawie uzyskanych wyników wyznaczono średnią, odchylenie standardowe, względne odchylenie standardowe i współczynnik zmienności. W celu zwiększenia czułości metody LC-MS/MS na podstawie analizy napięcia rozkładu cząsteczki w zakresie 0-300 V dokonano wyboru napięcia rozkładu cząsteczki DP $=80$. Ustalono odpowiednią energię kolizyjną (35 V). Wysoka rozdzielczość aparatu pozwoliła na wybranie wąskich przedziałów mas dla każdego związku: fentanyl- $\mathrm{d}_{5}-188,143 \pm 0,0047 \mathrm{Da}$, fentanyl $188,1445 \pm 0,0043$ Da i remifentanyl - 317,186 $\pm 0,007$ Da. 
Wyniki: Wyniki analizy fentanylu i remifentanylu pozwoliły na uzyskanie krzywych kalibracyjnych w zakresie 1-200 ng/mL które wykazały wymaganą liniowość.

Wniosek: Otrzymane wyniki umożliwiły identyfikację oraz ocenę ilościową fentanylu i remifentanylu we krwi pełnej.
Metoda LC-MS/MS znajduje zastosowanie zarówno w diagnostyce ostrych zatruć, monitorowaniu terapii, jak i praktyce orzeczniczo-sądowej.

Słowa kluczowe: fentanyl; remifentanyl; chromatografia cieczowa z tandemową spektrometrią mas.

\section{WSTĘP}

Mianem opioidów określa się grupę naturalnych i syntetycznych związków oddziałujących na organizm ludzki poprzez receptory opioidowe. Definicja ta obejmuje leki agonistyczne (morfina, fentanyl), agonistyczno-antagonistyczne (nalorfina) oraz antagonistyczne (nalokson). Związki te znalazły szerokie zastosowanie w neuroleptanalgezji oraz w znieczuleniu ogólnym, w którym wykorzystuje się przede wszystkim fentanyl, remifentanyl, alfentanyl i sufentanyl jako środki z wyboru, szczególnie u pacjentów z wysokim ryzykiem. Ponadto używa się ich w kardiochirurgii, gdzie łączone są ze środkami zwiotczającymi mięśnie $[1,2]$. Opioidy najczęściej stosowane w praktyce zamieszczono $\mathrm{w}$ tabeli 1 [3].

Wpływ opioidów na ośrodkowy układ nerwowy zależy od dawki, jaka powoduje analgezję, senność i tłumienie bólu. Z reakcji niepożądanych może wystąpić suchość w jamie ustnej, swędzenie twarzy, mogą też pojawić się dysforie, nudności, ewentualnie wymioty, może dojść do hiperalgezji, sztywności mięśni (przede wszystkim klatki piersiowej, brzucha i krtani) oraz drgawek mięśniowych i zwężenia źrenic [4, 5].

Opioidy często stosuje się łącznie z innymi środkami farmakologicznymi, ponieważ nie zapewniają całkowitego znieczulenia ogólnego. Występują w zestawieniu z benzodiazepinami, środkami zwiotczającymi mięśnie oraz wziewnymi środkami anestetycznymi, które wzmacniają ośrodkowe działania opioidów. Skojarzone z neuroleptykiem prowadzą do neuroleptanalgezji, stanu analgezji i neurolepsji, powodując obniżenie ciśnienia tętniczego, ale także osłabiając odruchy układu współczulnego na bodźce [4].

Fentanyl jest pochodną piperydyny. Strukturalnie występuje jako N-fenylo-N-[1-(2-fenyloetylo)piperydyn-4-ylo]proponamid. Charakteryzuje się wysoką litofilnością, dlatego szybko przedostaje się przez barierę krew-mózg. Po upływie 3-5 min od podania osiąga maksymalne działanie. Po wprowadzeniu pojedynczej dawki 1-3 $\mu \mathrm{g} / \mathrm{kg}$ m.c. działanie jest krótsze niż godzina, co uwarunkowane jest czasem biologicznego półtrwania. Fentanyl jest metabolizowany w wątrobie za pomocą cytochromu P4503A4 (CYP3A4) do nieczynnych metabolitów: 4-N-(n-propionyloanilino)-piperydyny i 4-N-(hydroksypropionylo-anilino)-piperydyny. Fentanyl w małych stężeniach 0,6-1 ng/mL wywołuje lekką analgezję, natomiast stężenie $1,5-5 \mathrm{ng} / \mathrm{mL}$ odpowiada przedziałowi od umiarkowanej do silnej analgezji. Stężenie tego leku w surowicy krwi w ilości 15-20 ng/mL odpowiada już za stan utraty świadomości [4]. Fentanyl wywołuje depresję oddechową, a jego wysokie stężenie może powodować sztywność mięśniową, która dodatkowo zaburza wentylację płuc. Opioid ten może mieć także wpływ na układ krążenia, doprowadzając do bradykardii, zaburzenia rytmu serca i spadku ciśnienia tętniczego [4].

Remifentanyl jest pochodną 4-anilinopiperydyny, chemicznie występuje jako chlorowodorek estru metylowego kwasu 3-(metoksykarbonylo)-4-(1-oksopropylo-fenyloamino)1-piperydyno-propionowego. Remifentanyl w porównaniu z innymi opioidami ma odmienną budowę [4]. Działa przeciwbólowo już po upływie $30 \mathrm{~s}$ od podania. Okres półtrwania wynosi 3-10 min, natomiast aktywność zanika w ciągu 5-10 min od zakończenia podawania. Klirens w osoczu tego związku wynosi 2,1-2,8 L/min [6].

Remifentanyl należy do związków lipofilnych, jednak jego rozpuszczalność w tłuszczach jest słabsza niż innych opioidów. Remifentanyl jako agonista ma praktycznie identyczne właściwości farmakologiczne jak fentanyl, sufentanyl oraz alfentanyl, jednak działa 6-10-krotnie silniej w porównaniu z pozostałymi pochodnymi [7]. Remifentanyl jak każdy agonista receptorów opioidowych powoduje depresję ośrodka

TABELA 1. Najczęściej stosowane w praktyce opioidy [3]

\begin{tabular}{|c|c|c|c|c|c|}
\hline Lek & $\begin{array}{l}\text { Dawkowanie na kg } \\
\text { m.c. }\end{array}$ & $\begin{array}{l}\text { Maksymalne } \\
\text { dziatanie }\end{array}$ & $\begin{array}{c}\text { Czas } \\
\text { działania }\end{array}$ & $\begin{array}{c}\text { Siła } \\
\text { dziatania }\end{array}$ & Uwagi \\
\hline Morfina & 5-10 mg i.v. & $30 \mathrm{~min}$ & 3-5 godz. & 1 & dostępność biologiczna 20-30\% \\
\hline Fentanyl & $\begin{array}{c}1-5 \mu \mathrm{g} \text { i.v. } \\
(0,1-0,3 \mathrm{mg} / 70 \mathrm{~kg})\end{array}$ & $5 \mathrm{~min}$ & $20-45 \mathrm{~min}$ & 100 & możliwość kumulacji \\
\hline Sufentanyl & $\begin{array}{c}0,3-5 \mu g \\
(10-50 \mu g / 70 \mathrm{~kg})\end{array}$ & $3 \mathrm{~min}$ & $30 \mathrm{~min}$ & 1000 & dopuszczony do podawania zewnątrzoponowego \\
\hline Alfentanyl & $\begin{array}{c}10-30 \mu g \\
(0,5-2 \mathrm{mg} / 70 \mathrm{~kg})\end{array}$ & $1 \mathrm{~min}$ & $10-15 \mathrm{~min}$ & 30 & - \\
\hline Remifentanyl & $0,05-1 \mu g / k g$ min & $1 \mathrm{~min}$ & $5 \mathrm{~min}$ & 100 & $\begin{array}{l}\text { u chorych w wieku podeszłym zmniejszenie dawki } \\
\text { o } 50 \% \text {, podawać we wlewie ciągłym }\end{array}$ \\
\hline Petydyna & $\begin{array}{c}\text { 0,5-1 mg i.v. } \\
(25-100 \mathrm{mg} / 70 \mathrm{~kg})\end{array}$ & $15 \mathrm{~min}$ & 2-4 godz. & 0,1 & korzystna w leczeniu dreszczy \\
\hline
\end{tabular}


oddechowego, proporcjonalną do dawki, może wywoływać sztywność mięśni, przede wszystkim w obrębie klatki piersiowej, uniemożliwiającej oddychanie spontaniczne, powoduje silną bradykardię oraz spadek ciśnienia krwi. Dość często po zastosowaniu remifentanylu mogą wystąpić nudności, wymioty oraz zaparcia $[4,6,8]$. Opioidy należą do grupy leków, których stężenie terapeutyczne powinno być w praktyce klinicznej indywidualnie monitorowane u pacjenta.

Biorąc pod uwagę cel kliniczny, poznawczy i zakres diagnostyczny badań podczas monitorowania leków, istotny jest dobór odpowiedniej metody analitycznej spełniającej wszystkie wymagania. Metodami najczęściej wykorzystywanymi w laboratoriach szpitalnych do oznaczania opioidów oraz ich pochodnych są techniki immunoenzymatyczne i fluorescencji w świetle spolaryzowanym. Obie metody charakteryzują się szeroką oznaczalnością, wysoką czułością i krótkim czasem wykonania analizy, ponieważ nie wymagają odrębnych technik izolacji z materiału biologicznego.

Niestety metody te nie są pozbawione wad. Ważnym problemem występującym podczas używania tych testów jest niespecyficzność reagowania w odniesieniu do poszczególnych pochodnych danej grupy farmakologicznej. Mogą wystąpić również reakcje krzyżowe wywołane przez inną grupę związków lub będące skutkiem wpływu matrycy biologicznej. Ponadto elementem utrudniającym pełną ocenę zależności ilościowych w badanym materiale jest częste zjawisko łącznego oznaczania wraz ze związkiem macierzystym jego metabolitów, których obecność może interferować w wartości bezwzględne uzyskanego wyniku [9, 10].

Dlatego coraz częściej w codziennej praktyce wykorzystuje się metody chromatograficzne pozwalające na oznaczanie zarówno związku czynnego, jak i jego metabolitów. Do metod tych zaliczane są wysokosprawna chromatografia cieczowa (HPLC), chromatografia gazowa (GC), które są zwykle sprzężone ze detektorem spektrometrii masowej (MS).

Zarów no HPLC, jak i GC są metodami uniwersalnymi, powszechnie stosowanymi w toksykologicznej analityce leków oraz innych związków chemicznych, pozwalającymi na precyzyjną weryfikację wyników uzyskiwanych metodami immunoenzymatycznymi. Metody te wymagają przed przeprowadzeniem analizy chromatograficznej etapu izolacji ksenobiotyku z materiału biologicznego i usunięcia matrycy biologicznej (tło biologiczne), co może utrudniać interpretację uzyskanych wyników. Obecnie dostępny jest i stosowany szeroki panel metod izolacji typu ciecz-ciecz czy typu cieczciało stałe [11].

Wykorzystana w pracy chromatografia cieczowa sprzężona ze spektrometrem mas (LC-MS) stanowi połączenie chromatografii cieczowej ze spektrometrią mas. Analizowane związki, które są rozdzielane w kolumnie chromatograficznej, przechodzą wraz z fazą ruchomą do detektora spektrometrii mas, gdzie ulegają jonizacji i fragmentowaniu. Pierwotnie zachodzi jonizacja z powstaniem jonów analitu w jonizatorze, a następnie ich detekcja poprzez określenie stosunku masy do ładunku (m/z) jonów. Identyfikacja przeprowadzana jest na podstawie analizy ich widma mas. Metodę LC-MS stosuje się do identyfikacji związków: polarnych, jonowych, termolabilnych i nielotnych. Najczęściej używane typy jonizacji w LC-MS to jonizacja na drodze elektrorozpylania (electrospray ionization - ESI) i jonizacja chemiczna pod ciśnieniem (APCI). Główne analizatory stosowane w LC-MS to: analizator czasu przelotu (TOF), kwadrupol i pułapka jonowa.

Połączenie chromatografii cieczowej ze spektrometrem mas gwarantuje dużą selektywność, wysoką czułość, rozdzielczość, powtarzalność, identyfikację poprzez masę oraz określenie struktury poprzez fragmentację, a także uniwersalność zastosowania [12].

Celem pracy było opracowanie metody dla jakościowego i ilościowego oznaczenia fentanylu oraz remifentanylu we krwi pełnej oraz wyznaczenie parametrów analitycznych.

\section{MATERIAŁY I METODY}

Wzorce: fentanyl o stężeniu $50 \mathrm{ug} / \mathrm{mL}$, remifentanyl o stężeniu $1 \mathrm{mg} / \mathrm{mL}$ i fentanyl deuterowany (fentanyl- $\mathrm{d}_{5}$ ) o stężeniu $100 \mathrm{ug} / \mathrm{mL}$ zostały zakupione w firmie LGC Gmbh (Certiline lab use).

Z oryginalnych roztworów wzorcowych przygotowano roztwory robocze o objętości $1 \mathrm{~mL}$, w których stężenia badanych substancji (fentanylu i remifentanylu) wynosiło $1 \mathrm{ug} / \mathrm{mL}$. Jednocześnie przygotowano roztwór roboczy deuterowanego standardu wewnętrznego (fentanyl- $\mathrm{d}_{5}$ ) o stężeniu $1 \mathrm{ug} / \mathrm{mL}$. Roztwory otrzymano poprzez rozcieńczenie wzorca macierzystego w roztworze metanol/woda $(1: 1, \mathrm{v} / \mathrm{v})$.

Wszystkie badania zostały przeprowadzone we krwi pełnej. Krew stanowiła łączną pulę populacyjną wykorzystywaną do dalszych badań.

Przed wykonaniem ekstrakcji przygotowano roztwory badane i kalibracyjne o objętości $1 \mathrm{~mL}$ poprzez obciążenie materiału biologicznego odpowiednią ilością roztworów roboczych. Stężenie wzorca wewnętrznego (fentanyl- $\mathrm{d}_{5}$ ) wynosiło 100 ng/mL w każdej próbce.

Próbki kalibracyjne obciążono roztworami roboczymi, osiągając następujące stężenia końcowe: $1 \mathrm{ng} / \mathrm{mL}, 50 \mathrm{ng} / \mathrm{mL}$, $100 \mathrm{ng} / \mathrm{mL}, 150 \mathrm{ng} / \mathrm{mL}, 200 \mathrm{ng} / \mathrm{mL}$ fentanylu oraz remifentanylu. Wyznaczano krzywe kalibracyjne w postaci stosunku pola powierzchni piku chromatograficznego do deuterowanego wzorca wewnętrznego (relative response factor - RRF). Granicę wykrywalności (limit of detection) wyznaczono na podstawie wartości stosunku sygnału do szumu (signal of noise ratio), a granica oznaczalności (limit of quantifaction) została wyznaczona na podstawie krzywych kalibracyjnych.

Powtarzalność między pojedynczymi wynikami analizy wyznaczono w oparciu o obliczone wartości odchyleń standardowych dla 5 powtórzeń próbek kontrolnych. Najczęściej stosowanymi miarami precyzji jest odchylenie standardowe (SD) oraz współczynnik zmienności (CV).

Metodyka ekstrakcji fentanylu i remifentanylu z krwi petnej Izolację fentanylu i remifentanylu przeprowadzono metodą ekstrakcji w układzie ciecz-ciecz (LLE). Do 500 uL obciążonej 
krwi umieszczonej w probówce wirówkowej dodawano $3 \mathrm{~mL}$ buforu boranowego o $\mathrm{pH}$ 9, odstawiono na $5 \mathrm{~min}$, a następnie dodano $6 \mathrm{~mL}$ octanu etylu. Całość wytrząsano przez $2 \mathrm{~min}$ i wirowano przez 5 min przy $4400 \mathrm{rpm}$ obr./min. Po odwirowaniu, pobierano $5 \mathrm{~mL}$ górnej warstwy organicznej, przenosząc ją do szklanej probówki na szlif i odparowywano do sucha w strumieniu azotu w temperaturze $40^{\circ} \mathrm{C}$. Suchą pozostałość rozpuszczano w $500 \mu \mathrm{L}$ 0,1\% roztworu kwasu mrówkowego.

\section{Analiza LC-MS/MS}

Uzyskane próbki poddawano analizie przy użyciu chromatografu cieczowego UHPLC firmy Eksigent ultraLC 110XL $\mathrm{z}$ autosamplerem, wyposażonego w pompę binarną pracującą w zakresie 5-50 $\mu \mathrm{L} / \mathrm{min}$. Separację próbek przeprowadzano na monolitycznej kolumnie chromatograficznej Merck Chromolithic Performance typu RP 18e, $3 \mu \mathrm{m}$, 100-2 mm. Objętość nastrzyku badanej próbki wynosiła 15 uL. Separacje próbek przeprowadzono w trybie gradientowym - przepływ fazy $400 \mu \mathrm{L} / \mathrm{min}$. Faza ruchoma: $\mathrm{H}_{2} \mathrm{O}-0,1 \% \mathrm{HCOOH}(\mathrm{A})$, acetonitryl-0,1\% HCOOH (B). Program gradientu składu fazy przedstawiał się następująco: 0-1 min 98\% A, 1-6 min 98\% B, 9-10 min 98\% A.

Spektrometr masowy firmy AB Sciex TripleTOF 5600+, typu QqTOF (Quadrupole/Quadrupole/Time of Flight), źródło jonów DuoSpray sprzężone z automatycznym podajnikiem roztworu kalibracyjnego z kapilarą APCI. Jonizacja typu ESI w trybie dodatnim, temperatura $350^{\circ} \mathrm{C}$, przepływ gazów (azot) 40/20/25 (kurtyna), energia kolizyjna (CE) 35V ze zmianą CES 15 . Tryb skanowania: MS/MSHR - 136,100/91,056/118,086 w zakresie 100-1000 Da 150 ms, MS/MS-IDA (z automatyczna korekcją tła) 5 jonów 50 ms 50-1000 Da.

Analizę wyników przeprowadzono z wykorzystaniem dedykowanego oprogramowania dostarczonego przez producenta MultiQuant Analyst TF ver. 1.6, które przeszukuje bibliotekę widm masowych z użyciem programu PeakVie ${ }^{\circledR}$ Soft ware v 2.1.2 Master View - identyfikacja poprzez analizę rozkładów izotopowych, masę izotopową, bibliotekę widm LibrarView Forensic dla MS/MS oraz Molecular Formule Generator. Parametry analizy wysokosprawnej chromatografii cieczowej sprzężonej z tandemowym spektrometrem mas (LC-MS/MS) przedstawiono w tabeli 2 .

\section{WYNIKI}

W celu wytworzenia charakterystycznej fragmentacji cząsteczek i maksymalnej transmisji pożądanych jonów wybrano napięcie rozkładu cząstki 80 (DP, Declustering), a także energię kolizyjną (35 V), przy której jon macierzysty danej substancji jest obecny na chromatogramie i towarzyszą mu jony potomne.

Próbki analizowano w zakresie standardowym dla badanych substancji, jaki najczęściej wykorzystuje się w badaniach leków - m/z 50-650 Da.

Specyficzność metody ustalono poprzez wyznaczenie chromatografu całkowitego prądu jonowego oraz chromatografów wybranych prądów jonowych dla poszczególnych związków w trybie q/TOF (MS/MS) - ryciny 1-4.

\section{Widma masowe}

Dla określenia struktury poszczególnych związków poddano je fragmentacji typu MS/MS. Uzyskano widma masowe charakterystyczne dla cząstek, na które rozpadają się dane związki. Dla fentanylu-d $\mathrm{d}_{5}$ uzyskano cząstki o masach: 188,1, 105,07 Da. Widmo MS/MS dla fentanylu, to cząstki o masach 188,1 i 105,07 Da, a dla remifentanylu: 345,1, 317,1, 285,1, 261,1, 228,1, 202,1, 196,0, 168,1, 158,1, $146,1,136,1,116,1,113,1,84,0,81,0$ Da. Uzyskane widma masowe dla poszczególnych związków przedstawiono na rycinach 5-7.

\section{Wydajność}

W celu obliczenia wydajności przygotowano serię 5 próbek zawierających po $50 \mathrm{ng} / \mathrm{mL}$ badanych analitów. Próbka odniesienia o takim samym stężeniu nie była poddawana ekstrakcji (100\%), a kolejne próbki poddano procedurze ekstrakcji. Wydajność ekstrakcji dla fentanylu i remifentanylu zostały przedstawione w tabeli 3 .

TABELA 3. Wydajność ekstrakcji dla fentanylu i remifentanylu

\begin{tabular}{|c|c|c|}
\hline \multirow{2}{*}{ Nr próbki } & Fentanyl & Remifentanyl \\
\hline & \multicolumn{2}{|c|}{ odzysk R (\%) } \\
\hline 1 & 68,70 & 66,71 \\
\hline 2 & 56,75 & 55,12 \\
\hline 3 & 71,35 & 71,03 \\
\hline 4 & 61,46 & 62,60 \\
\hline Xśr. & 64,56 & 63,86 \\
\hline SD & 6,68 & 6,77 \\
\hline RSD & 0,10 & 0,11 \\
\hline CV (\%) & 10,35 & 10,60 \\
\hline
\end{tabular}

Xśr - średnia; SD - odchylenie standardowe; RSD - względne odchylenie standardowe; CV - współczynnik zmienności

\section{Krzywe kalibracyjne, liniowość}

W celu wykreślenia krzywych kalibracyjnych i oznaczenia liniowości przygotowano 3 serie po 5 próbek, które zawierały $100 \mathrm{ng} / \mathrm{mL}$ wzorca wewnętrznego fentanylu- $\mathrm{d}_{5}$ oraz fentanyl

TABELA 2. Warunki analizy LC/MS/MS (wybrane parametry analityczne)

\begin{tabular}{lcccc}
\multicolumn{1}{c}{ Substancja } & DP (V) & CE (V) & Rt (min) & Jon frag. (Da) \\
\hline Fentanyl d $d_{5}$ & 80 & 35 & 3,39 & 188,144 \\
\hline Fentanyl & & & 3,40 & 342,260 \\
\hline Remifentanyl & & & 2,97 & 337,229 \\
\hline
\end{tabular}

DP - napięcie rozkładu cząsteczki; CE - energia kolizyjna; Rt - czas retencji; Jon frag. - jon fragmentaryczny; [M+H] ${ }^{+}-$jon molekularny (macierzysty) 


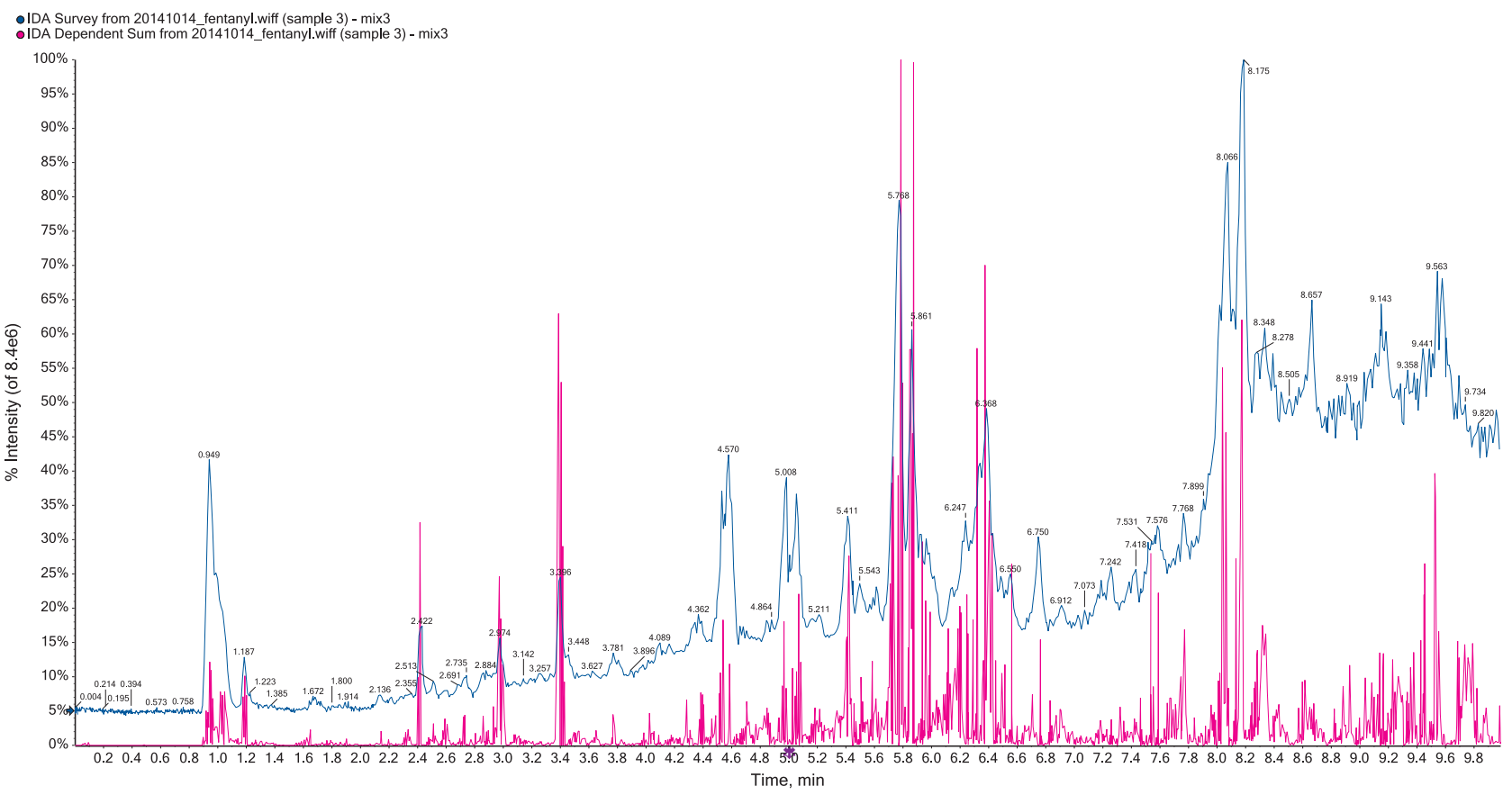

RYCINA 1. Chromatogram catkowitego prądu jonowego dla fentanylu, remi fentanylu i fentanylu- $d_{5}$

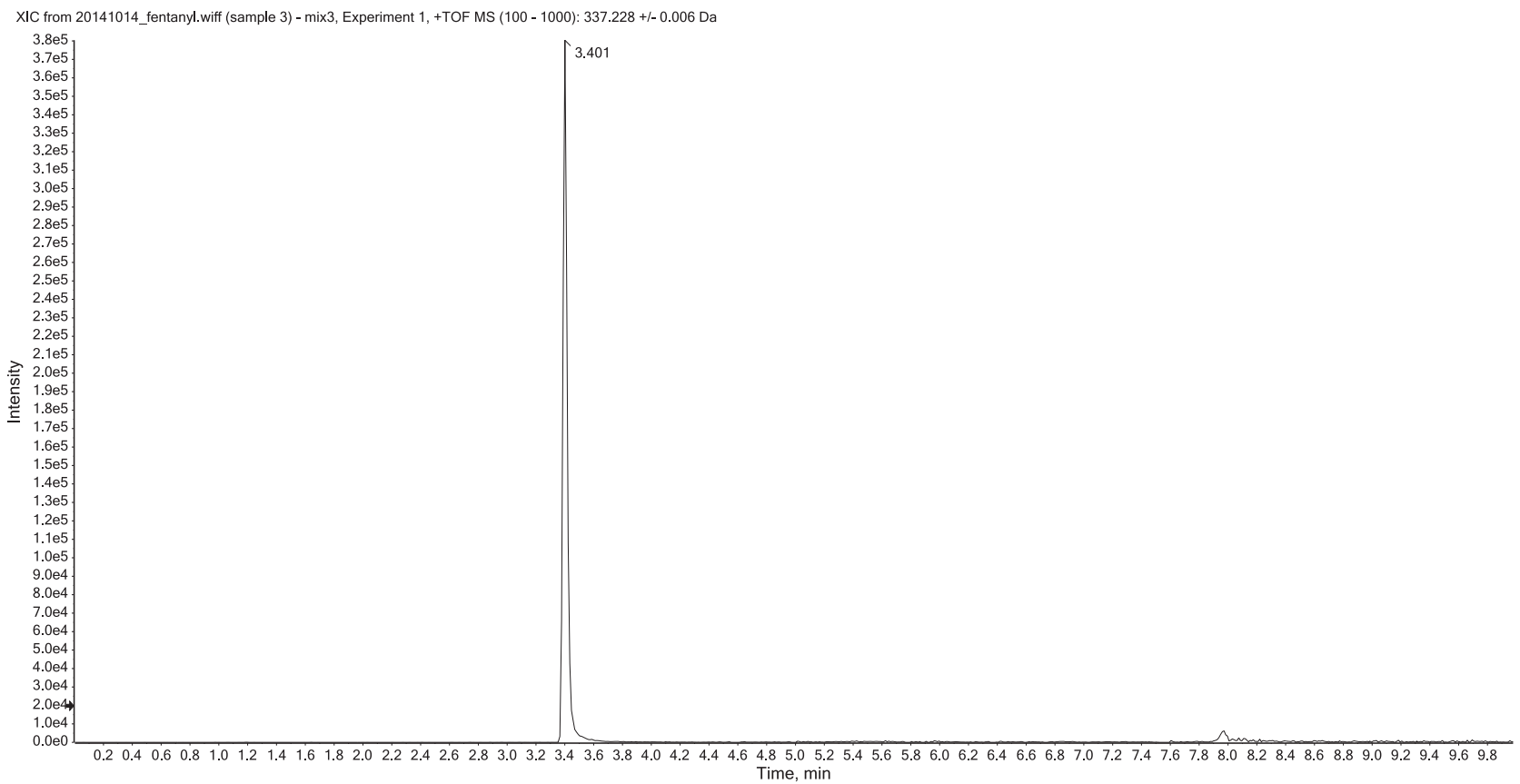

RYCINA 2. Chromatogram wybranego prądu jonowego dla fentanylu, m/z 337

i remifentanyl o stężeniach: $1 \mathrm{ng} / \mathrm{mL}, 50 \mathrm{ng} / \mathrm{mL}, 100 \mathrm{ng} / \mathrm{mL}$, $150 \mathrm{ng} / \mathrm{mL}, 200 \mathrm{ng} / \mathrm{mL}$. Dla wszystkich serii próbki zostały uzyskane przez zastosowanie LLE. Równanie regresji liniowej oraz współczynnik korelacji dla każdego związku przedstawiono na rycinach 8 i 9.

Limit wykrywalności dla każdego badanego związku wynosił 0,5 ng/mL, natomiast wartość granicy oznaczalności wynosiła $1 \mathrm{ng} / \mathrm{mL}$ dla wszystkich badanych związków.

Powtarzalność (zgodność między pojedynczymi wynikami analizy) wyznaczono w oparciu o obliczone wartości odchyleń standardowych dla 5 powtórzeń próbek kontrolnych, w których stężenie fentanylu i remifentanylu wynosiło $10 \mathrm{ng} / \mathrm{mL}$ (tab. 4 i 5 ).

\section{OMÓWIENIE WYNIKÓW I DYSKUSJA}

W badaniach klinicznych coraz częściej wykorzystywanymi metodami analitycznymi są techniki chromatograficzne łączone ze spektrometrią mas. Znajdują one zastosowanie w diagnostyce ostrych zatruć, monitorowaniu poziomów leków, badaniach farmakokinetyki i farmakodynamiki. 


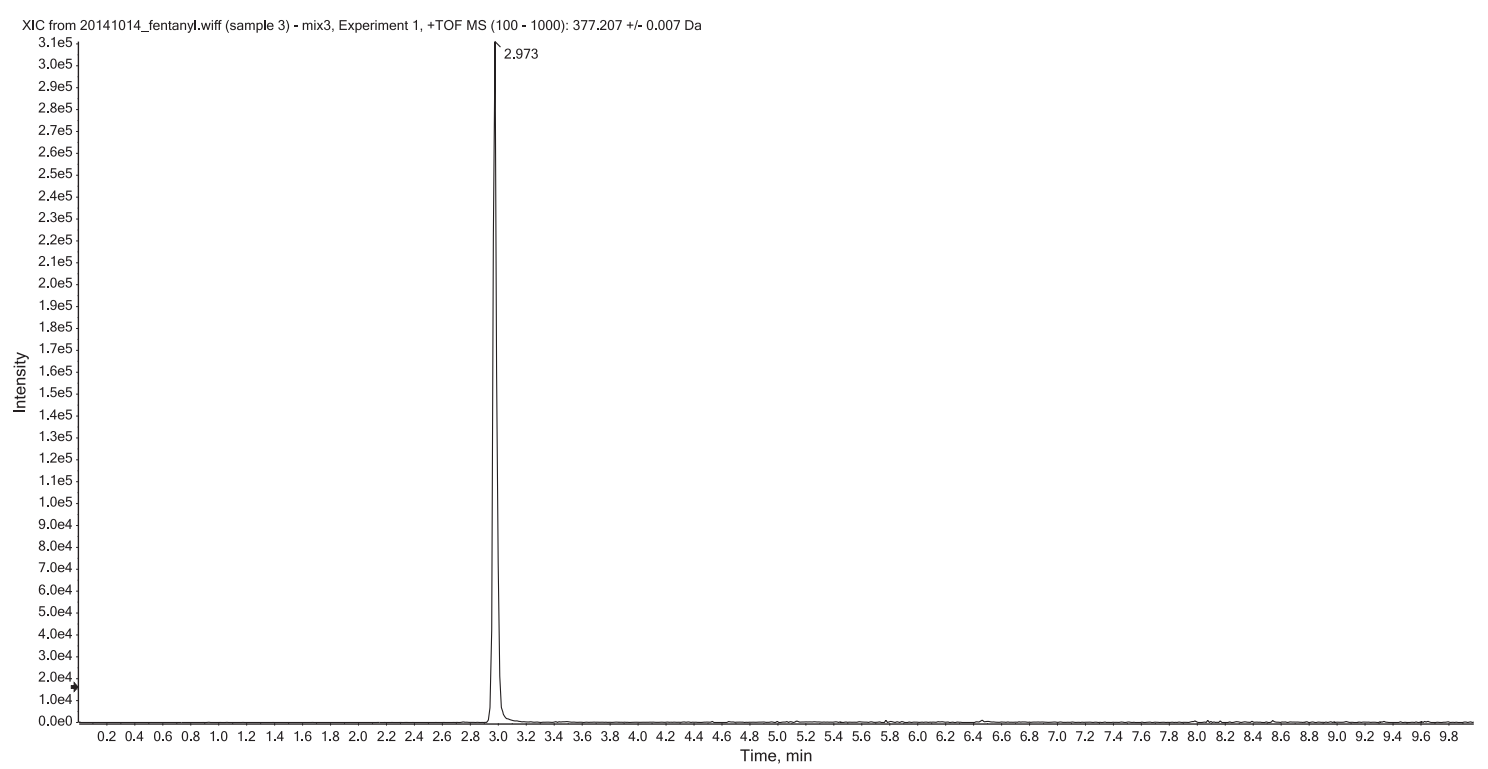

RYCINA 3. Chromatogram wybranego prądu jonowego dla remifentanylu, $\mathrm{m} / \mathrm{z} 377$

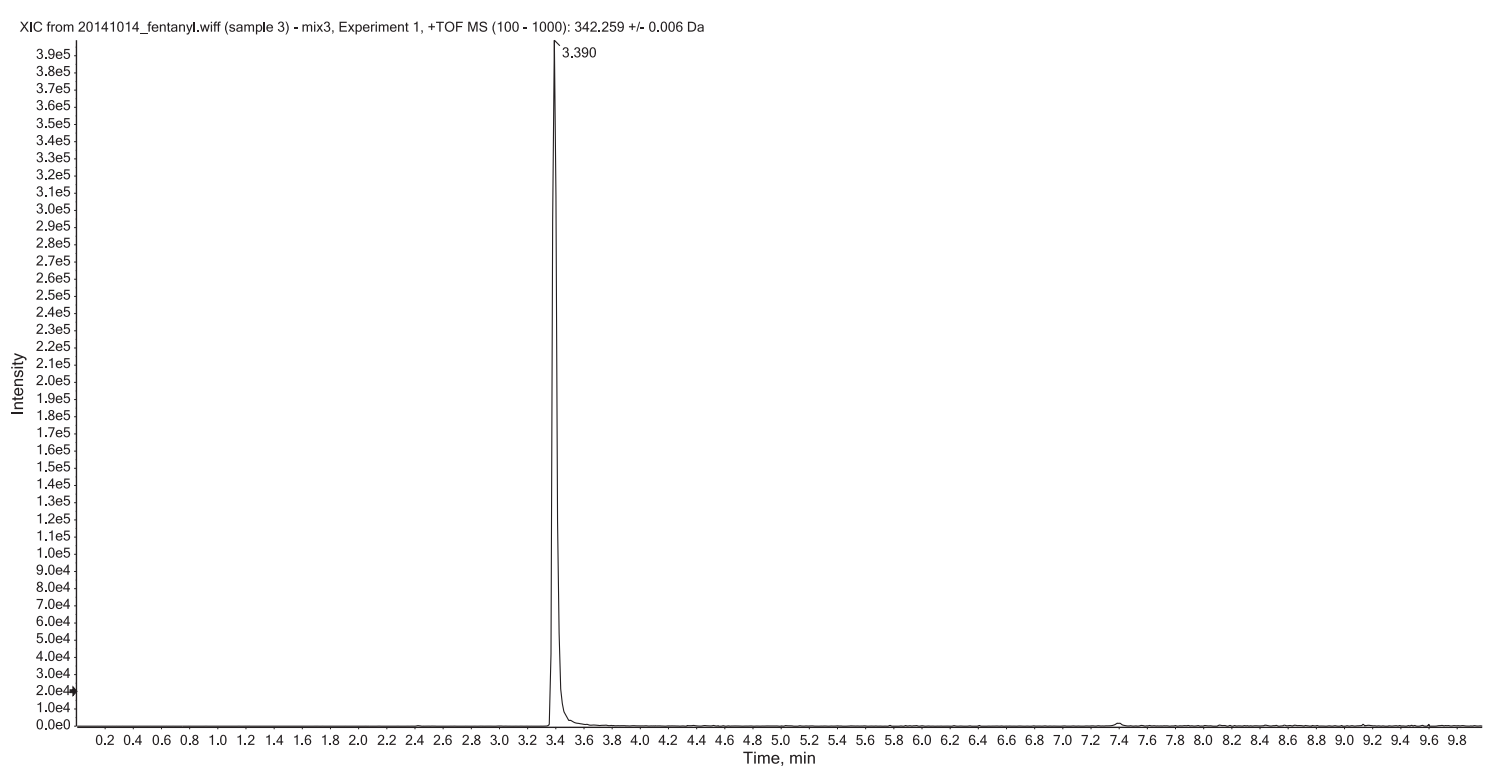

RYCINA 4. Chromatogram wybranego prądu jonowego dla fentanylu- $d_{5}, m / z 342$

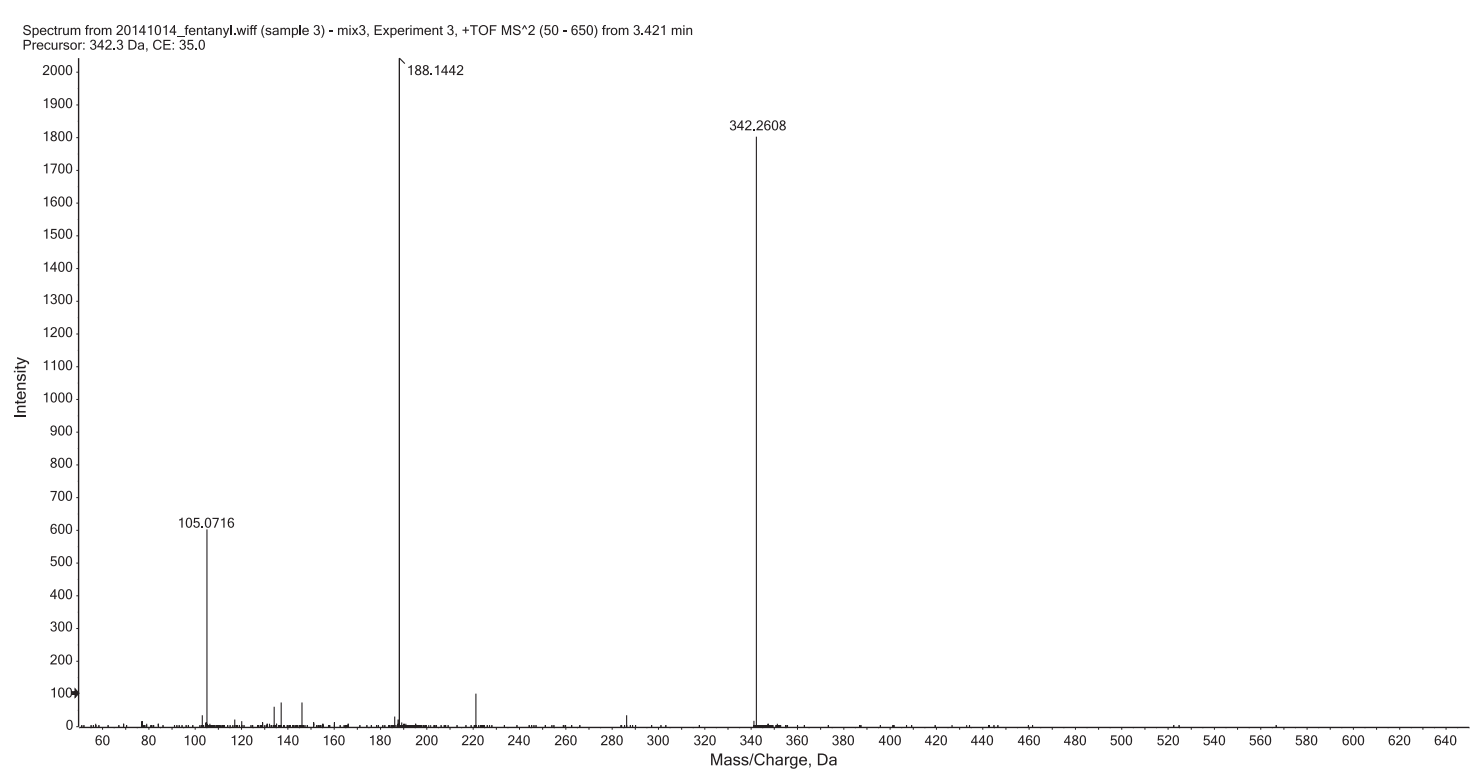

RYCINA 5. Widmo masowe MS/MS dla fentanylu- $d_{5}$ 


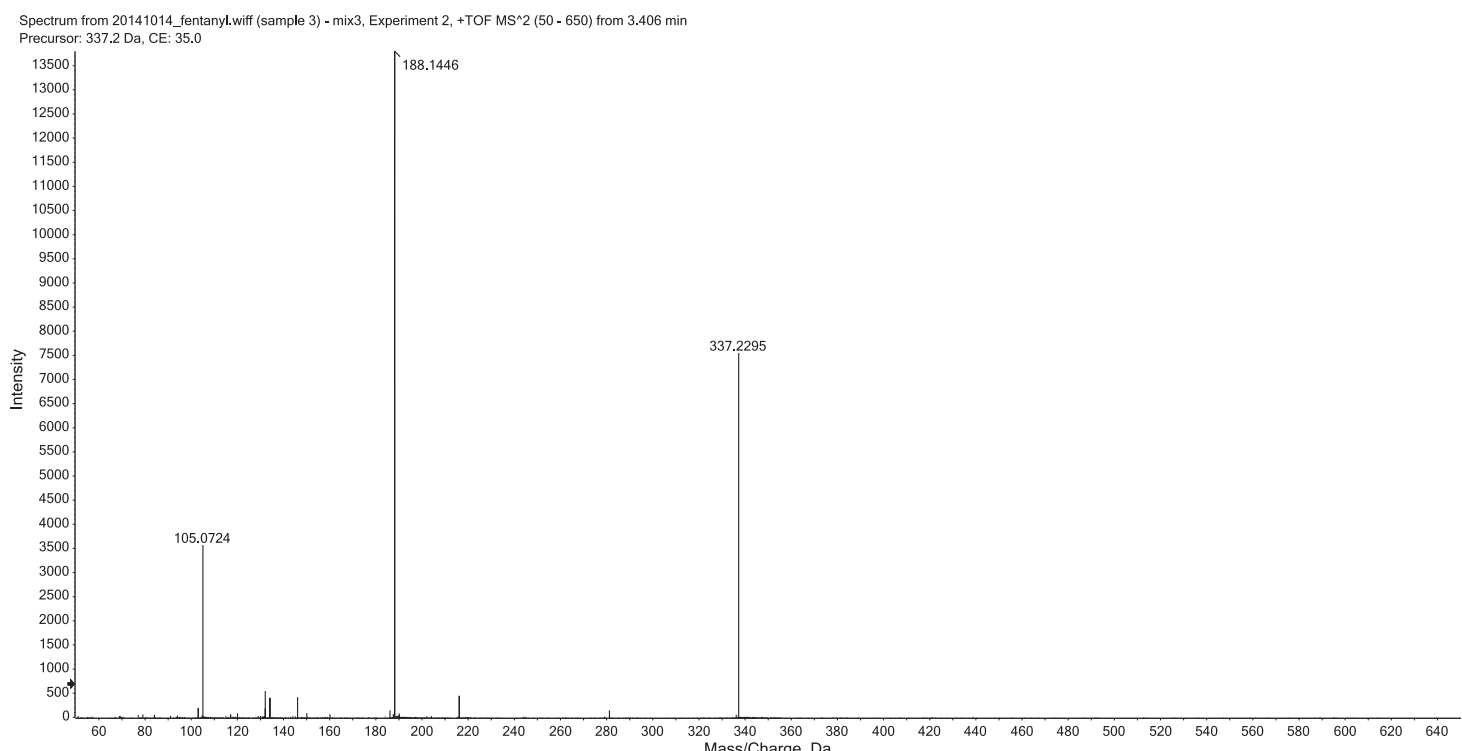

RYCINA 6. Widmo masowe MS/MS dla fentanylu

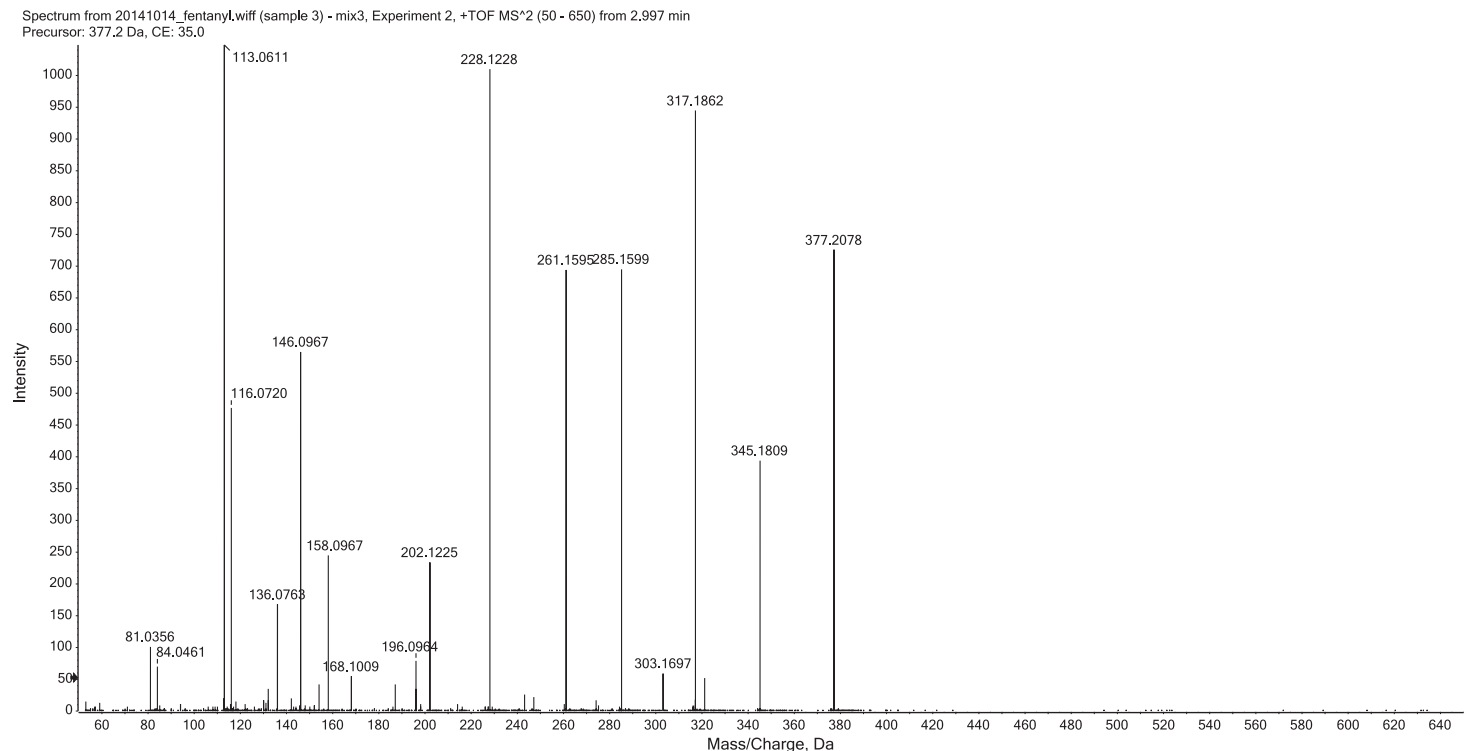

RYCINA 7. Widmo masowe MS/MS dla remifentanylu

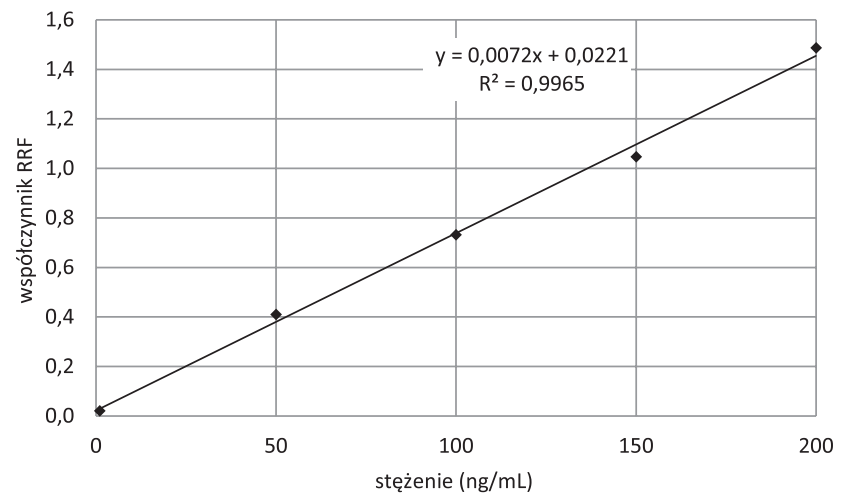

RRF - deuterowany wzorzec wewnętrzny (relative response factor)

RYCINA 8. Krzywa kalibracyjna dla fentanylu

Ponadto mogą być używane w celach kontroli dopingowej i narkotykowej jak również do oceny ryzyka narażenia zawodowego i środowiskowego na szkodliwe substancje. Terapia

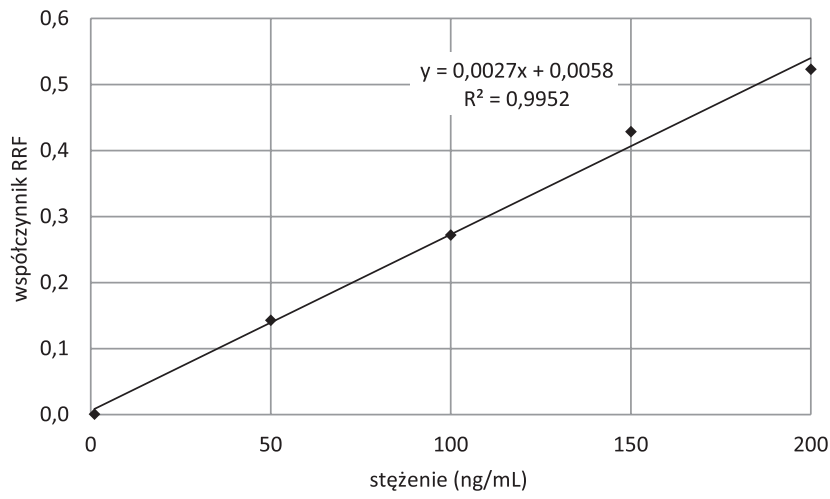

RRF - deuterowany wzorzec wewnętrzny (relative response factor)

RYCINA 9. Krzywa kalibracyjna dla remifentanylu

monitorowana stężenia leku we krwi (therapeutic drug monitoring) ma na celu zapewnienie optymalnych stężeń terapeutycznych leku. 
TABELA 4. Powtarzalność dla fentanylu

\begin{tabular}{|c|c|c|}
\hline $\begin{array}{l}\text { Stężenie } \\
\text { (ng/mL) }\end{array}$ & $\begin{array}{c}\text { Stężenie oznaczone } \\
\text { (ng/mL) }\end{array}$ & $\begin{array}{c}\text { Dokładność } \\
(\%)\end{array}$ \\
\hline \multirow{5}{*}{10} & 10,00 & 100,02 \\
\hline & 10,26 & 102,64 \\
\hline & 9,83 & 98,30 \\
\hline & 10,58 & 105,80 \\
\hline & 9,31 & 93,11 \\
\hline Xśr & 10,00 & - \\
\hline SD & 0,48 & - \\
\hline RSD & 0,05 & - \\
\hline CV (\%) & 4,77 & - \\
\hline
\end{tabular}

Xśr - średnia; SD - odchylenie standardowe; RSD - względne odchylenie standardowe; CV - współczynnik zmienności

TABELA 5. Powtarzalność dla remifentanylu

\begin{tabular}{lcc}
\multirow{2}{*}{$\begin{array}{c}\text { Stężenie } \\
\text { (ng/mL) }\end{array}$} & $\begin{array}{c}\text { Stężenie oznaczone } \\
(\mathbf{n g} / \mathrm{mL})\end{array}$ & $\begin{array}{c}\text { Dokładność } \\
(\%)\end{array}$ \\
\hline & 9,38 & 93,81 \\
\cline { 2 - 3 } 10 & 10,79 & 107,91 \\
\cline { 2 - 3 } & 10,74 & 107,37 \\
\cline { 2 - 3 } & 9,80 & 98,03 \\
\hline Xśr stężenie & 9,37 & 93,67 \\
\hline oznaczone & 10,02 & - \\
\hline SD & 0,71 & - \\
\hline RSD & 0,07 & - \\
\hline CV $(\%)$ & 7,04 & -
\end{tabular}

Xśr - średnia; SD - odchylenie standardowe; RSD - względne odchylenie standardowe; CV - współczynnik zmienności

W orzecznictwie sądowo-lekarskim techniki te stosowane są w przypadkach związanych z zatruciami śmiertelnymi, a jako materiał biologiczny wykorzystuje się zarówno krew, jak i mocz. Dla celów klinicznych, głównie związanych z monitorowaniem stężenia leków w trakcie leczenia, najważniejsza jest pełna krew lub surowica [13].

Istnieje kilka możliwości łączenia omawianych technik analitycznych. Rozwiązaniami, po które najczęściej się sięga, są: chromatografia gazowa sprzężona ze spektrometrem mas (GC-MS), chromatografia gazowa - tandemowa spektrometria mas (GC-MS/MS), chromatografia cieczowa sprzężona ze spektrometrem mas (LC-MS), LC-MS/MS. Spotyka się także $\mathrm{w}$ literaturze zastosowanie metody UHPLC-MS/MS [14].

Każde współczesne laboratorium, które ma spełniać warunki atestacji wykonywanych badań, jest zmuszone we własnym zakresie wdrażać, modyfikować, udoskonalać i walidować poszczególne procedury oznaczeń przy wykorzystaniu posiadanej aparatury i sprzętu pomiarowego. Każdorazowo konieczne jest zatem ustalenie odpowiedniego zakresu metody, który będzie odpowiedni dla celu badań, obowiązujących norm populacyjnych oraz w zakresie stężeń spotykanych w konkretnych przypadkach klinicznych czy też sądowych.

Stężenia terapeutyczne omawianych opioidów są niskie i wynoszą od 10-100 ng/mL dla fentanylu oraz 3-50 ng/mL dla remifentanylu, dlatego aby można było je skutecznie wykryć w materiale biologicznym, potrzebne jest zastosowanie metody o wysokiej czułości. Niewątpliwie przydatną metodą, która pozwala na oznaczenie stężeń ksenobiotyków w tak niskich poziomach terapeutycznych, jest LC-MS $[15,16]$.

Jednak zasadniczym elementem osiągnięcia wiarygodnych wyników monitorowanych leków jest ich skuteczna ekstrakcja z matrycy biologicznej oraz odpowiedni dobór parametrów rozdziału chromatograficznego i detekcji. W praktyce najczęściej stosowane są metoda LLE oraz ekstrakcja na kolumnach wypełnionych podłożem stałym (SPE). Częstość wykorzystania obu technik jest porównywalna. Ekstrakcja LLE jest powszechnie stosowana, ponieważ jest względnie tania i prosta w wykonaniu w porównaniu z SPE. Niemniej jednak dobranie optymalnych warunków ekstrakcji dla kilku substancji może sprawiać trudność, a jeśli te substancje mają diametralnie różne właściwości fizykochemiczne, może to skutkować spadkiem wydajności ekstrakcji dla któregoś z analitów. Stosując metodę SPE, można uzyskać większą wydajność procesu i lepsze oczyszczenie próbki z interferujących związków oraz eliminować problem związany z tworzeniem się emulsji. Jest to jednak procedura wieloetapowa i pracochłonna, co przekłada się na koszt wykonywanej analizy [17, 18].

Mathlke i wsp. przedstawili procedury ekstrakcji z krwi i moczu. W obu przypadkach były to ekstrakcje typu LLE, które nieco się od siebie różniły. Anality we krwi ekstrahowano wodorotlenkiem amonu i octanem etylu, natomiast w moczu wodorotlenkiem sodu oraz octanem etylu. Dla porównania wykonano ekstrakcję z użyciem chlorku n-butylu, lecz skuteczniejsza okazała się ekstrakcja octanem etylu [13].

Jinling i wsp. zaprezentowali natomiast ekstrakcję dla remifentanylu do fazy stałej, której wydajność osiągnęła 94\%, jednakże opisana procedura ekstrakcji była wieloetapowa i czasochłonna [19].

W niniejszej pracy przedstawiono własną metodykę ilościowego oznaczenia fentanylu i remifentanylu z wykorzystaniem ekstrakcji LLE i dalszą analizą za pomocą LC-MS/MS.

Wydajność opisywanej ekstrakcji wynosiła dla fentanylu $64,56 \%$, a dla remifentanylu 63,86\% (tab. 3). Wartości wyników uzyskanych dla obu związków są zbliżone. Wydajność w procesie jednoczesnej ekstrakcji jest niższa w porównaniu z niektórymi doniesieniami naukowymi. Podkreślić jednak należy, że opisane wcześniej procedury dotyczyły odrębnych procesów ekstrakcji dla poszczególnych pochodnych opioidowych. U Skulskiej i wsp. [16] wydajność ekstrakcji dla fentanylu wyniosła 96\%, a dla remifentanylu 82\%, natomiast w publikacji Skulskiej i wsp. [17] wartości wynosiły odpowiednio 84,6\% i 90,7\% [16, 17].

Poszczególne związki poddano fragmentacji MS/MS, uzyskując widma masowe dla danej substancji, i monitorowano następujące jony: dla fentanylu m/z 337, remifentanylu m/z 377 i fentanylu- $\mathrm{d}_{5} \mathrm{~m} / \mathrm{z} 342$.

Wykazano, że zastosowana metoda zachowuje liniowość w zakresie stężeń 1-200 ng/mL, co spełniało wymogi zakresu stężeń opisywanych w literaturze klinicznej. Krzywe kalibracyjne zostały wykreślone jako stosunek sygnału analitu do sygnału wzorca wewnętrznego i jego zależność od stężenia 
analitu, przedstawiony równaniem $\mathrm{y}=\mathrm{ax}+\mathrm{b}$. Przy kalibracji wykorzystano metodę wzorca wewnętrznego. Jako wzorzec wewnętrzny zastosowano fentanyl- $\mathrm{d}_{5}$ (pochodna deuterowana fentanylu), który jest substancją odniesienia oraz charakteryzuje się budową chemiczną i fizyczną podobną do badanych związków. Metoda wzorca wewnętrznego używana jest do niwelowania wpływu parametrów operacyjnych metody na odpowiedź analitu. Uzyskane krzywe kalibracyjne dla badanych związków cechowały dobre współczynniki korelacji, 0,997 dla fentanylu oraz 0,995 dla remifentanylu. Współczynnik determinacji równania regresji liniowej $\left(\mathrm{R}^{2}\right)$ był zatem podobny do uzyskiwanych przez innych badaczy. W pracy Skulskiej i wsp. współczynnik korelacji wynosił dla fentanylu 0,996, a remifentanylu 0,998 [17]. Z kolei Jinling i wsp. uzyskali dla remifentanylu współczynnik korelacji równy 0,9991 [19].

Dokładność przeprowadzonych oznaczeń nie przekraczała dopuszczalnych $\pm 15 \%$ stężeń rzeczywistych; dla fentanylu wynosiła 93,11-105,80\%, a dla remifentanylu 93,81-107,91\%. Współczynnik zmienności wynosił dla fentanylu 4,77\%, a dla remifentanylu 7,04\%.

Jak się wydaje, przedstawione parametry metody, spełniające wymogi praktyki laboratoryjnej (CV <10\%, dokładność $\pm 15 \%$ ), umożliwiają jej praktyczne zastosowanie dla jednoczesnego oznaczania w materiale biologicznym fentanylu oraz remifentanylu.

Uzyskane rezultaty wskazują, że stężenie fentanylu oraz remifentanylu można jednocześnie i w sposób zadawalający kontrolować przez 24 godz. po podaniu dożylnym nawet pojedynczej dawki. Metoda może być również pomocna w celu dokładnego i szybkiego pomiaru stężeń fentanylu oraz remifentanylu zarówno w rutynowych badaniach klinicznych, jak i w przypadku ekspertyz sądowych [13].

Chromatografia cieczowa sprzężona z tandemową spektrometrią mas ze względu na szybkość analizy, wysoką selektywność oraz czułość ma coraz szersze zastosowanie w analizie klinicznej, toksykologicznej i sądowej, stając się metodą referencyjną. Czułość tej metody jest 100-1000-krotnie wyższa niż czułość klasycznej chromatografii cieczowej połączonej z detektorem typu UV/Vis lub Diode Array. Zastosowanie LC-MS/MS umożliwia analizę jakościową oraz ilościową złożonych mieszanin, a ciągły rozwój technologiczny dotyczący nowych detektorów oraz aplikacji dedykowanych poszerza możliwości ich wykorzystywania.

\section{WNIOSEK}

Otrzymane przy zastosowaniu opracowanej procedury analitycznej wyniki umożliwiają jednoczesną identyfikację oraz ocenę ilościową fentanylu i remifentanylu w próbce krwi pełnej. Przedstawiona procedura z wykorzystaniem LC-MS/MS znajduje zastosowanie zarówno w toksykologii klinicznej, jak i sądowej.

\section{PIŚMIENNICTWO}

1. Krajnik M, Żylicz Z. Mechanizmy działania przeciwbólowego opioidów. Pol Med Paliatywna 2013;2:111-8.

2. Barash P, Cullen B, Stoelting R. Podstawy farmakologiczne praktyki anestezjologicznej. In: Barash P, Cullen B, Stoelting R. Podręcznik anestezjologii klinicznej. Warszawa: PZWL; 1995.

3. Weinert M. Znieczulenie ogólne. In: Kruszyński Z, editor. Podstawy anestezjologii i intensywnej terapii. Poznań: Wyd. Nauk. AM; 2006.

4. Larsen R. Opioidy. In: Kubler A, editor. Anestezjologia. Tom 1. Wrocław: Elsevier Urban \& Partner; 2013.

5. Orońska A. Działania niepożądane opioidów. Pol Med Paliatywna 2008;2(4):155-63.

6. Podlewski J. Leki współczesnej terapii. Warszawa: Medical Tribune Polska; 2009.

7. Egan T. Remifentanil pharmacokinetics and pharmacodynamics. A preliminary appraisal. Clin Pharmacokinet 1995;29(2):80-94. doi: 10.2165/00003088-199529020-00003.

8. Knapik M, Misiołek H, Knapik P, Dyczyńska-Herman A. Remifentanyl ultrakrótko działający nowy środek opioidowy - możliwości zastosowania w anestezjologii. Wiad Lek 2005;58:353-7.

9. Wachowiak R. Ocena toksykologiczna metod diagnostycznych stosowanych w zatruciach środkami psychoaktywnymi. Przegl Lek 2001;58: 215-9.

10. Bertol E, Vaiano F, Furlanetto S, Mari F. Cross-reactivities and structure-reactivity relationships of six benzodiazepines to EMIT immunoassay. J Pharm Biomed Anal 2013;84:168-72. doi: 10.1016/j.jpba.2013. 05.026.

11. Brandys J. Toksykologia - wybrane zagadnienia. Kraków: WUJ; 1999.

12. Kała M. Problemy toksykologa analityka w dobie technik sprzężonych. Probl Forensic Sci 2008;75:228-46.

13. Mahlke NS, Ziesenitz V, Mikus G, Skopp G. Quantitative low-volume assai for simultaneous determinantion of fentanyl, norfentanyl, and minor metabolites in human plasma and urine by liquid chromatography-tandem mas spektrometry (LC-MS/MS). Int J Legal Med 2014;128(5):771-8. doi: 10.1007/s00414-014-1040-y.

14. Radziwoń-Zalewska M, Matsumoto H, Skalski M, Biernacka-Bazyluk A. Stosowanie technik monitorujących w leczeniu depresji. Część II. Terapia monitorowana stężeniem leku we krwi. Farmakoter Psychiatr Neurol 2011;3-4:129-33.

15. Winek CL, Wahba WW, Winek CL Jr, Balzer TW. Drug and chemical blond level data 2001. Forensic Sci Int 2001;122(2-3):107-23.

16. Skulska A, Kała M, Adamowicz P, Chudzikiewicz E, Lechowicz W. Oznaczanie fentanylu, atropiny i skopolaminy w materiale biologicznym metodami LC/MS/APCI. Przegl Lek 2007;64:263-7.

17. Skulska A, Kała M, Parczewski A. Determination of fentanyl and its analogues in toxicological expert analyses. Probl Forensic Sci 2005;63: 227-34.

18. Potocka-Banaś B, Borowiak $K$, Wachowiak R, Janus T. Zastosowanie faz stałych do izolacji wybranych związków organicznych z materiału biologicznego. Diagn Lab 2006;42(1):75-84.

19. Jinling L, Yanhua L, Hau J, Yao S, Qinghai X, Yang Y. Solid-phase extraction combined with UHPLC-MS/MS method for determination of remifentanil in human whole blond. Abingdon: Taylor \& Francis; 2012. p. 1134-42. 